\title{
Combined evaluations of meteorological parameters, traffic noise and air pollution in an Alpine valley
}

\author{
Dietrich Heimann ${ }^{1 *}$, Klaus Schäfer $^{2}$, Stefan Emeis $^{2}$, Peter Suppan $^{2}$, Friedrich $^{2}$ \\ OBLEITNER $^{3}$ and ULRICH UHRNER ${ }^{4}$ \\ ${ }^{1}$ DLR, Institut für Physik der Atmosphäre, Oberpfaffenhofen, Weßling, Germany \\ ${ }^{2}$ Karlsruher Institut für Technologie (KIT), Institut für Meteorologie und Klimaforschung, Bereich \\ Atmosphärische Umweltforschung, Garmisch-Partenkirchen, Germany \\ ${ }^{3}$ Universität Innsbruck, Institut für Meteorologie und Geophysik, Innsbruck, Austria \\ ${ }^{4}$ Technische Universität Graz, Institut für Verbrennungskraftmaschinen und Thermodynamik, Graz, Austria
}

(Manuscript received October 13, 2008; in revised form December 10, 2009; accepted January 11, 2010)

\begin{abstract}
Concurrent measurements of meteorological parameters, traffic flow and vehicle composition, $\mathrm{NO}_{\mathrm{x}}$ concentrations and noise levels have been performed during a consecutive 166-hour (approx. one week) episode in the Austrian Inn valley. The study elaborates the meteorologically induced effects on the transport and dispersion of air pollutants $\left(\mathrm{NO}_{\mathrm{x}}\right)$ and the propagation of sound waves from the motorway in the valley towards two receptor/receiver sites, one at the valley bottom, the other one at an elevated slope position. Due to complex transmission effects only a small portion of the observed variations in the air and noise pollution at the two sites can be explained by the varying emission at the motorway. With the help of simple models it is shown that by adding merely one or two meteorological parameters a substantially larger portion of the variation can be explained. The vertical temperature gradient turned out to be the meteorological key parameter. It controls the mixing volume (confined by the valley sides and the mixing-layer top) and the sound wave refraction which strongly determine air pollution and noise level, respectively.

Zusammenfassung

Zeitgleiche Messungen von meteorologischen Parametern, dem Verkehrsfluss und der Fahrzeugzusammensetzung, sowie der $\mathrm{NO}_{\mathrm{x}}$-Konzentration und des Lärmpegels wurden während einer zusammenhängenden, 166 Stunden langen Episode (ca. eine Woche) im österreichischen Inntal durchgeführt. Die Studie beschreibt die meteorologischen Effekte auf die Ausbreitung der Luftverunreinigung $\left(\mathrm{NO}_{\mathrm{x}}\right)$ und des Lärms von der Autobahn im Tal zu zwei Messpunkten am Talboden und an einer höher gelegenen Hangposition. Als eine Folge der komplexen Ausbreitungseffekte lässt sich an den beiden Messpunkten nur ein kleiner Teil der beobachteten Schwankungen durch die zeitliche Änderung der jeweiligen Emission erklären. Mit Hilfe einfacher Modelle wird gezeigt, dass sich bei Hinzufügung von lediglich einem oder zwei meteorologischen Parametern ein weitaus größerer Anteil der beobachteten Schwankungen erklären lässt. Dabei stellte sich der vertikale Temperaturgradient als ein Schlüsselparameter heraus. Er steuert das Mischungsvolumen (begrenzt durch die Talflanken und die Obergrenze der Mischungsschicht) und die Schallwellenbrechung, die die Luftverschmutzung bzw. den Lärmpegel stark bestimmen.
\end{abstract}

\section{List of abbrevations}

AGL above ground level

ASL above sea level

CET Central European Time (= UTC +1 hour)

MLH Mixing-layer height

AD Altmahd (measurement site at the valley bottom for noise)

AZ Arzberg (measurement site at the valley slope for meteorology, air pollution, and noise)

HP Heliport Schwaz (site at the valley bottom for Sodar measurements)

PL Pill (traffic counting station at the B171 federal road)

\footnotetext{
*Corresponding author: Dietrich Heimann, Institut für Physik der Atmosphäre, Oberpfaffenhofen, 82234 Weßling, Germany, e-mail:

Dietrich.Heimann@dlr.de
}

SZ Schwaz (measurement site at the valley bottom for meteorology and air pollution)

VP Vomp (traffic counting station at the A12 motorway)

The term 'immission' is used as a synonym for the ambient air pollution concentration and the noise level at the receptor/receiver.

\section{Introduction}

Major Alpine valleys are often densely populated and traversed by busy roads and railway lines. Hence, air pollution and noise are serious environmental nuisances. Air and noise pollution often appear in combination and result in cumulative effects on the health and well-being of the local population. The Alpine topography engraves these problems because of the following facts: (1) The transport infrastructure is limited to a rather small 